\title{
The role of lipids in nonenzymatic browning
}

\author{
By Francisco J. Hidalgo and Rosario Zamora
}

Instituto de la Grasa, CSIC, Avenida Padre García Tejero 4, 41012 Sevilla, Spain

\section{RESUMEN}

\section{El papel de los lípidos en el pardeamiento no enzimático}

En este trabajo se hace una revisión del papel de los lípidos en el pardeamiento no enzimático de alimentos mediante el estudio de las reacciones proteína/lípido oxidado en comparación con otras reacciones donde ocurre también este oscurecimiento: la reacción de Maillard, el pardeamiento producido por el ácido ascórbico, y las reacciones de las quinonas con los grupos amino. Los mecanismos propuestos para estas reacciones de producción de color y fluorescencia, así como la formación de melanoidinas, lipofuscinas y productos coloreados de bajo peso molecular son discutidos de forma comparada, concluyendo que el papel de los lípidos en estas reacciones no parece ser muy diferente del papel de los carbohidratos en el Maillard o de los fenoles en el pardeamiento enzimático. Estas reacciones carbonil-amino parecen ser un grupo de reacciones secundarias que ocurren de forma gradual, son parcialmente reversibles, son universales e inevitables y ocurren en alimentos y en sistemas biológicos. Sin embargo, la mayoría de estos resultados han sido obtenidos en sistemas modelo y estudios adicionales deberían ser abordados en sistemas más cercanos a los alimentos y a lo seres vivos, lo que debería repercutir en un mejor entendimiento del pardeamiento no enzimático y, en definitiva, nos daría una visión más completa de la bioquímica de los alimentos y de los seres vivos.

PALABRAS-CLAVE: Interacciones proteína-lípido oxidado - Pardeamiento no enzimático - Reacción de Maillard Reacciones amino-carbonilo.

\section{SUMMARY}

\section{The role of lipids in nonenzymatic browning}

The role of lipids in nonenzymatic browning is studied by reviewing oxidized lipid/protein reactions in comparison with other reactions where the production of browning is known: the Maillard reaction, the ascorbic acid browning, and the quinone/amine reactions. The mechanisms proposed in these reactions for production of color and fluorescence, as well as the formation of melanoidins, lipofuscins, and low molecular weight colored products are discussed comparatively, concluding that the role of lipids in these reactions does not seem to be very different to the role of carbohydrates in the Maillard reaction or the phenols in the enzymatic browning. These carbonyl-amine reactions seem to be a group of gradual, partially reversible, universal, and inevitable side reactions in both food and biological systems. However, most of these results were obtained in model systems and additional studies should be carried out in systems closer to real foods or living beings, which should provide a more complete understanding of nonenzymatic browning, and, therefore, to afford a much more comprehensive knowledge of food and human biochemistry.

KEY-WORDS: Amino-carbonyl reactions - Maillard reaction Nonenzymatic browning - Oxidized lipid-protein interactions.

\section{INTRODUCTION}

When we select foods and when we eat, we use all of our physical senses, including sight, touch, smell, taste, and even hearing. These senses allow us to determine food quality, which can be divided into three main categories: appearance, textural and flavor factors (Francis, 1999; Ghorpade et al. 1995; Potter and Hotchkiss, 1995). Appearance factors include such things as size, shape, wholeness, different forms of damage, gloss, transparency, color, and consistency. Textural factors include handfeel and mouthfeel of firmness, softness, juiciness, chewiness, grittiness. And flavor factors include both sensations perceived by the tongue which include sweet, salty, sour, and bitter, and aromas perceived by the nose. Most of these factors have been thoroughly studied during the last decades because they are closely related to the acceptability of foods, and some of them are nowadays clearly understood. However, many others are only partially understood and their study continues at present. The objective of the present study is to update the contribution of nonenzymatic browning reactions to food colors by reviewing recent papers appeared in relation to the mechanisms involved in oxidized lipid/protein reactions.

\section{THE COLOR AS A FUNCTIONAL PROPERTY}

Color is often the first sensory quality by which foods are judged, and it may also provide an indication of chemical changes suffered by them. Color is the general name for all sensations arising from the activity of the retina of the eye. When lights reaches the retina, the eye neural mechanism respond, signaling color among other things. According to this definition, color (like flavor and texture) cannot be studied without considering the human sensory system. The color perceived when the eye views an illuminated object is related to three factors: the spectral composition of the light source, the chemical and physical 
characteristics of the object, and the spectral sensitivity properties of the eye. To evaluate the properties of the eye, the other two factors must be standardized. Fortunately, the characteristics of different people's eyes for viewing colors are fairly uniform, and it is not too difficult to replace the eye by instruments that provide consistent results. There are several systems of color classification. The most important is the CIE system (Commission International de l'Eclairage). Other systems used to describe food colors are the Munsell, Hunter, and Lovibond systems (Acton and Dawson, 1994; MacDougall, 1994; deMan, 1999; Pomeranz and Meloan, 1978).

Food colors are the result of a variety of factors both endogenous and exogenous to the food that may be affected by genetics and pre and postharvested treatments. The exogenous factors consist of such things as packaging films, display lights, and processing, while the endogenous factors involve pigments within the food, added colors, and physical characteristics that affect glossiness and haze (Clydesdale, 1998; Francis, 1993).

With few exceptions, food pigments can be divided into five groups: tetrapyrrole compounds (chlorophylls, hemes, and bilins), isoprenoid derivatives (carotenoids), benzopyran derivatives: (anthocyanins and flavonoids), betanidin derivatives (betalains), and artefacts (those produced during processing and storage, mainly melanoidins and caramels). Reviews for the chemistry and stability of the pigments included in the first four groups have appeared recently, and they will not be reviewed in the present study (Belitz and Grosch, 1999; Boileau at al., 1999; von Elbe and Schwartz, 1996; Francis, 1985; Hendrich et al., 1999; Hendry and Houghton, 1996; deMan, 1999; Mínguez at al., 1999).

\section{CONTRIBUTION OF FOOD BROWNING TO THE COLOR OF FOODS}

In addition to natural pigments, the color of foods may be modified by a series of reactions among food constituents which produce the consequence commonly termed as food browning (Friedman, 1996; Sapers, 1993). Although these reactions sometimes produce negative consequences for the quality of foods, others are desirable, and the addition of both natural pigments and induced colors may increase greatly the acceptability of foods. Thus, browning of salmon fillet, sometimes encouraged by the addition of sugar, occurs during smoking. This lead to a variation of color of smoked salmon slices, which are partly pink and partly brown. The appearance of a slice of good quality smoked salmon is due to a delicate interplay between the natural pink pigment, the imposed browning, and the translucent nature of the flesh (Hutchings, 1994).

Food browning is mostly the consequence of a series of reactions of amines, amino acids, peptides, and proteins with reducing sugars, oxidized lipids, vitamin $C$ and quinones. The reaction with quinones is known as enzymatic browning because the quinones are usually produced enzymatically from phenols, and the others are grouped as nonenzymatic browning reactions. Although, the nonenzymatic oxidation of phenols has also been described after alkaline treatments, this reaction is thought to produce browning by similar mechanisms to the enzymatic browning and will not be described independently (Hurrell and Finot, 1985; Finot, 1997; Mauron, 1986).

Browning reactions in foods are more complex than is suggested by the simple classification of these reactions as enzymatic or nonenzymatic, because of the large number of secondary reactions that may occur. For example, pre-peeled potatoes may develop red, brown, or even black discolorations, sometimes on opposite sides of the same tuber (Feinberg et al., 1987). These discolorations are the result of enzymatic browning reactions, but nonenzymatic «after-cooking darkening», induced by heating during steam or lye peeling, also may contribute to discoloration of the peeled surface (Smith 1987). Similarly, mushrooms undergoing enzymatic browning may develop pink, brown, black, gray, or even purple stains, in some cases, by reactions that are poorly understood (Nichols, 1985). Discolorations may occur in some raw products in which endogenous or added ascorbic acid is oxidized to dehydroascorbic acid, which then reacts with amino acids to yield brown colors by the Maillard reaction or other nonenzymatic means (Kacem et al., 1987). These are only some examples that illustrate how all these reactions are interrelated and, sometimes, the classification of a specific effect as produced by only one type of mechanism may impede a clear understanding of the different reactions involved.

\subsection{Enzymatic browning}

Enzymatic browning is a reaction caused by cell descompartmentation, which occurs in both plant and animal tissues. This reaction causes discoloration on the surfaces of some fruits and vegetables (e.g., potato, mushroom, apple, banana) and in the meat adjacent to the exoskeleton of crustacean species (e.g., crab, shrimp, lobster) (Haard, 1992). On the other hand, enzymatic browning is a desired reaction in processes like tea fermentation, drying of dates, and cocoa fermentation (Haard, 1998; Haard and Chism, 1996). 
Figure 1 shows the mechanism of the reaction. The reaction takes place in several successive steps, and the browning is a consequence of the hydroxylation of monophenolic compounds present in foods that are lately oxidized to o-benzoquinones. The initial reaction may involve monophenol monooxygenase or tyrosinase, and the main reaction is catalyzed by the diphenol oxidases, catechol oxidase, or laccase. Catechol oxidase is also referred to as polyphenoloxidase or phenolase and appears to be a widespread enzyme in foodstuff. Laccase, and to a lesser extent monophenol monooxygenase, does not appear to be widespread in nature. The benzoquinones formed are very reactive and condense and react nonenzymatically with other phenolic compounds, amino acids, etc., to produce melanoidin pigments of indeterminate structure (Hutchings, 1994; Osuga et al., 1994; Sapers, 1993). Polymerization to melanoidins involve Michael addition to the benzene ring of the very reactive o-benzoquinone. Some polymerization products are soluble and colors range from yellow, brown, red, green and

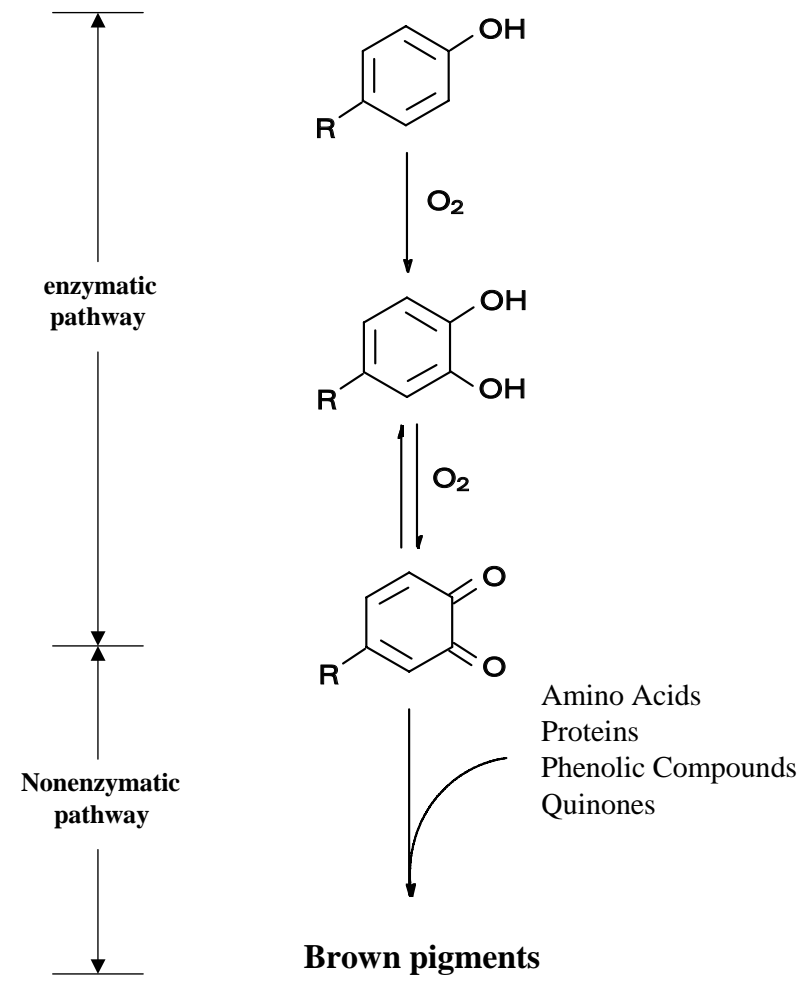

Figure 1

Formation of brown pigments as a consequence of enzymatic browning blue depending on the extent of polymerization and nature of chromophoric groups (Osuga et al., 1994). There are three groups of phenolic compounds that occur in food material and participate in enzymatic browning reactions: simple phenols (e.g., tyrosine, catechol, and gallic acid), cinnamic acid derivatives (e.g., p-coumaric acid, caffeic acid, and chlorogenic acid), and flavanoids (e.g., chatechin, quercetin, and leucoanthocyanidin) (Eskin, 1990). The enzymes are relatively heat labile and can be inhibited by acids, halides, phenolic acids, sulfites, chelating agents, reducing agents such as ascorbic acid, quinone couplers as cysteine, and various substrate-binding compounds (Sapers, 1993).

Some authors have also suggested that porphyrins such as heme and melanins can also be oxidized to dehydroporphyrin and dehydromelanin quinone-like intermediates, which can undergo related browning-type reactions (Friedman, 1996).

\subsection{Nonenzymatic browning}

The nonenzymatic browning of foods is the consequence of a complex series of chemical reactions among different food components. Although this type of browning is frequently considered to be produced by carbohydrate-protein reactions (the Maillard reaction), other food components have also been shown to play a role in this browning, which also takes place under conditions in which the Maillard reaction would be very difficulty produced.

The Maillard reaction is the nonenzymatic glycosidation of amino acids or proteins to form glycated products. It embraces a whole network of different reactions in which an extraordinary complex mixture of compounds are obtained in very different amounts. In foods, this reaction takes place essentially between the monosaccharides, glucose and fructose, or the disaccharides, maltose and lactose, as well as in some cases (e. g., meat) reducing pentoses, and amino acids and/or proteins. The first step of the reaction is the formation of a $N$ substituted glycosylamine from an aldose (or ketose) reacting with a primary amino group of an amino acid, peptide, or protein. This glycosylamine suffers then an Amadori rearrangement type of reaction to yield a 1-amino-1-deoxy-2-ketose. The next step of the reaction is the dehydration or fragmentation of the sugar, or the Strecker degradation to produce both amino or nonamino compounds. Finally, the condensation of the products formed in the previous step is produced either among them or with amino compounds to form brown pigments and polymers. (Danehy, 1986; Deyl and Miksik, 1997; Hodge, 1953; Hurst, 1972; Ikan, 1996; Labuza and Baisier, 1992; Ledl and Schleicher, 1990; Namiki, 1988; 
O'Brien et al., 1998). Figure 2 summarizes these reactions.

If the reaction mixtures of sugars and amines are submitted to exclusion chromatography, fractions

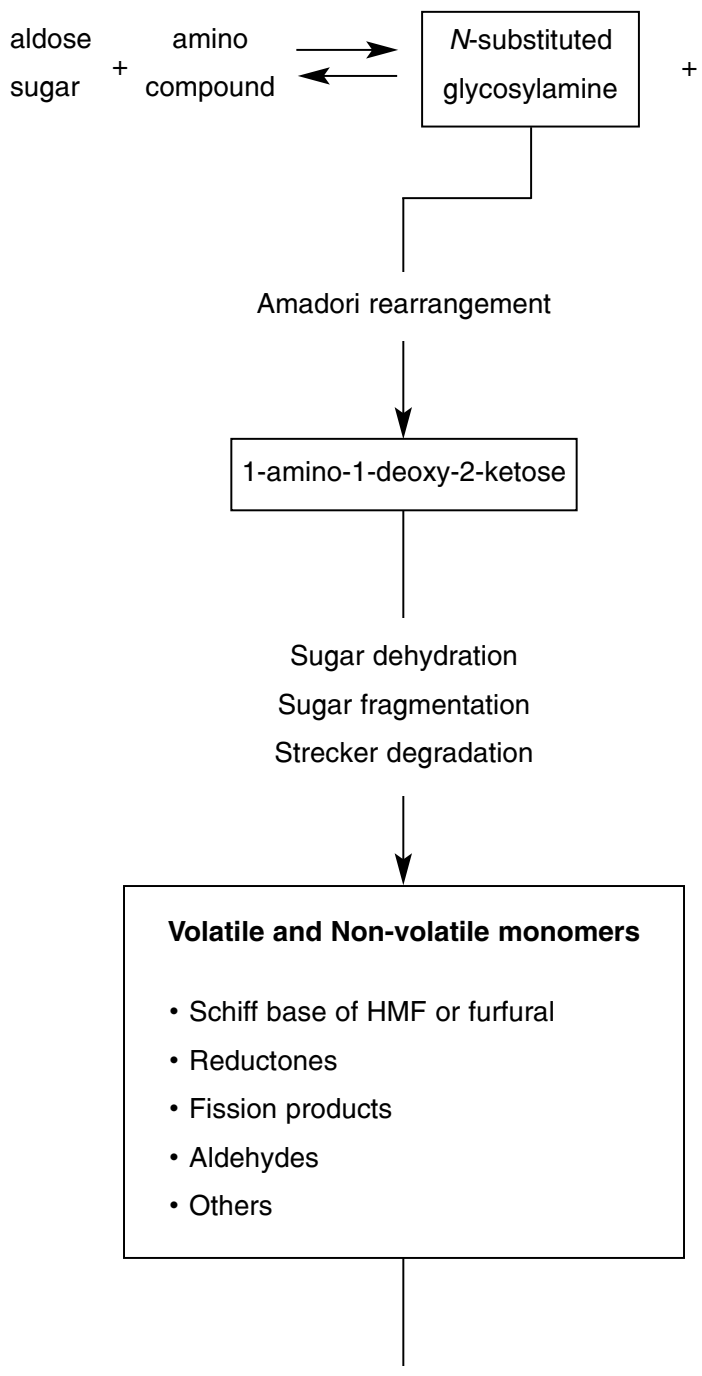

Aldol condensation

Carbonyl-amine polymerization

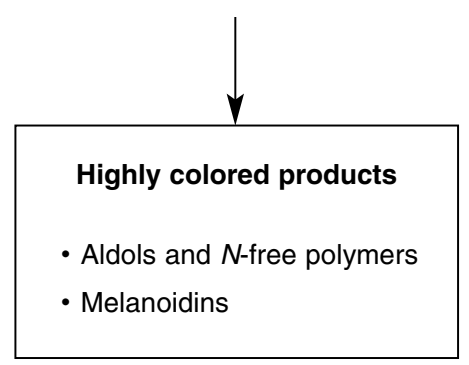

Figure 2

The Maillard reaction pathway can be obtained with molecular weights of about $7000 \mathrm{Da}$ and even greater, and these fractions are predominant (> 95\% p. w.) (Tressl et al., 1998b). However, so far it has not yet proved possible to isolate homogeneous high molecular weight Maillard products, and very little is known about the structure of these products, the so-called melanoidins. In addition, ${ }^{1} \mathrm{H}$ and ${ }^{13} \mathrm{C}-\mathrm{NMR}$ spectra of the melanoidins isolated by different research groups differed substantially, and melanoidins with groups of signals that largely resemble those of Amadori compounds (Kato and Tsuchida, 1981; Olsson et al. 1981) contrast with those that exhibit signals in the olefin, aromatic, and carbonyl regions (BenzingPurdie and Ratcliffe, 1986; Feather and Huang, 1986; Huang and Feather, 1988; Kato et al., 1986). These results seem to indicate both a variety of melanoidin structures and the difficulty to purify these polymers that can absorb monomers and these last compounds are probably appearing in the spectra. Additional studies with ${ }^{15} \mathrm{~N}$-labeled amino acids showed that the melanoidins obtained exhibited signals in the pyrrole, indole, and amide region of the ${ }^{15} \mathrm{~N}-\mathrm{NMR}$ spectrum (Benzing-Purdie and Ratcliffe, 1986). These last results seem to be, at least partially, in agreement with the polypyrrolic structure proposed recently for these melanoidin-like Maillard polymers (Tressl et al., 1998a, 1998b), which is also very similar to the structure previously proposed for the melanoidins produced by oxidized lipid/protein reactions, see below (Hidalgo and Zamora, 1993a).

In addition to these macromolecular colored products, the isolation and identification of low molecular weight colored Maillard products has been described but, so far, they have only been achieved in model systems (Arnoldi et al, 1997; Hashiba, 1986; Hofmann, 1998; Ledl and Severin, 1981; Ledl and Severin, 1982; Ledl et al., 1983; Nursten and O'Reilly, 1983; Obretenov and Argirov, 1986; Tsuchida et al., 1975).

If the carbohydrate is heated at high temperature in the absence of amino compounds, browning is also produced by a reaction mechanism named caramelization. These reactions are supposed to be similar to those produced in carbohydrates when they are submitted to strong acid or alkaline media: enolizations and fragmentations of the sugar molecule followed by additional secondary reactions (Belitz and Grosch, 1999). Commercial caramels are produced with ammonia or ammonium salts resulting in electropositive or electronegative caramels, respectively. The composition and coloring power of caramel depends on the type of raw materials and the process used. Both Maillard-type reactions and pure caramelizing reactions are thought to be involved, and the commercial product is extremely complex in 
composition. Caramels contain high and low molecular weight colored compounds, as well as a variety of volatile components (Heyns and Klier, 1968; deMan, 1999; Theander, 1981).

In addition to glycation reactions, oxidation of ascorbic acid also plays an important role in the nonenzymatic browning of foods (Gregory, 1996; Handwerk and Coleman, 1988; Namiki, 1988; Pischetsrieder et al., 1998; Yin, 1996). The mechanism of this nonenzymatic browning is summarized in Figure 3. Decomposition of ascorbic acid is rapid in an alkaline medium and is much slower at a pH less<smiles>[R]C1OC(=O)C(O)=C1O</smiles>

HO<smiles>CO</smiles><smiles>[R]C1OC(=O)C(=O)C1=O</smiles><smiles>N[C@H](C(=O)[OH+])[C@@H](N)C(=O)O</smiles><smiles>[Z]C1OC(=O)C(N)=C1O</smiles><smiles>[R]C1OC(=O)C(=O)C1=O</smiles><smiles>[R]C1OC(=O)C(N)=C1O</smiles>

\section{Brown pigments}

Figure 3 than 7 in the absence of metal catalysts. Oxidation starts with the formation of the dehydroascorbic acid (DHA), which may further suffer a series of reactions with amino compounds leading to the active formation of pigments and flavors. Initially, the reaction of dehydroascorbic acid with an $\alpha$-amino acid produces the scorbamic acid (SCA), which in the next step is converted into a red pigment that has been identified as 2,2'-nitrilodi-2(2)-deoxy-L-ascorbic acid ammonium salt. This pigment suffer then further polymerizations to produce melanoidin-like polymers. The reactions of dehydroascorbic acid with proteins in the presence of water also produced rapid browning although no 2,2'-nitrilodi-2(2)-deoxy-Lascorbic acid ammonium salt was obtained.

The last group of compounds that have been implicated in nonenzymatic browning are the lipids. They will be discussed in the next section.

\section{THE ROLE OF LIPIDS IN NONENZYMATIC BROWNING}

The role of lipids in the nonenzymatic browning reactions is a consequence of its liability to be oxidized. Lipid oxidation is one of the two most important reactions in food systems. It is the cause of important deteriorative changes in food flavor, color, texture, and nutritional value. It may also result in formation of toxic and mutagenic agents. On the other hand, oxidation of lipids is also an important source of flavor compounds considered desirable. The above features are common also to the other complex of reactions in foods which shares the key importance in food technology: the Maillard reaction described above. Furthermore, both reactions are linked by complex interactions. Maillard reactions may be initiated, and final composition affected by products of lipid oxidation. Conversely lipid oxidation is known to be affected by products of nonenzymatic browning, some of which are antioxidants (Ahmad et al., 1998; Alaiz et al., 1996a, 1997a; Arnoldi et al. 1990; Franke and Iwainsky, 1954; Karel, 1992; Zamora et al., 1997).

Autoxidation of fats is the main reaction involved in the oxidative deterioration of lipids, although in foods the lipids can be oxidized by both enzymatic and nonenzymatic mechanisms. Nonenzymatic oxidation or autoxidation of fats proceeds via typical free radical mechanisms and hydroperoxides are the initial products. They are relatively unstable and enter into numerous complex reactions involving substrate degradation and interaction, resulting in a myriad of compounds of various molecular weights, flavor thresholds, and biological significance (Berdeaux et al., 1999; Frankel, 1998; Gasparoli, 1998; Hidalgo et al., 1991; Kamal-Eldin and Appelqvist, 1996; Nawar, 1996, 1998). 
The enzymatic oxidation of lipids takes place sequentially. Lipolytic enzymes release polyunsaturated fatty acids that are then oxidized by either lipoxygenase or cyclooxygenase to form hydroperoxides or endoperoxides, respectively. The next sequence of events involves enzymatic cleavage or transformation of the hydroperoxides and endoperoxides to yield a variety of breakdown products in addition to a broad series of oxidized long chain fatty acids, which are often responsible for the characteristic flavors of natural products and for some important physiological functions (Gardner, 1975, 1980, 1985, 1989, 1997; Grechkin, 1998; Piazza, 1996; Zamora et al., 1991a, 1991b).

One of the reactions described for the lipid oxidation products has been their polymerization to produce brown-colored oxypolymers (Buttkus, 1975; Khayat and Schwall, 1983; Venolia and Tappel, 1958). However, in the presence of other compounds (e. g., proteins, antioxidants, etc.), oxidative reactions (both enzymatic and nonenzymatic) can be terminated by reactions with compounds other that those originating from oxidation of the lipid substrate, and this can influence reaction rates and produce significant consequences in the color, flavor and texture of foods. Particularly, the reaction of lipid oxidation products with amines, amino acids, and proteins has long been related to both the browning observed in many fatty foods during processing and storage (El-Zeany and Fattah, 1982; Gillatt and Rossell, 1992; Hidalgo et al., 1992; Pokorny, 1998; Stansby, 1957) and the progressive accumulation of age-related yellow-brown pigments (lipofuscins) in man and animals (Aubourg, 1998; Miquel et al., 1977; Porta and Hartroff, 1969; Sohal, 1981; Strehler, 1964; Yin, 1996). In addition, a direct relationship between fluorescence and browning has been found in diverse studies (Adhikari and Tappel, 1973; Hidalgo and Zamora, 1993b).

In the field of the role of lipids in the nonenzymatic browning of foods, Stansby (1957) first noticed the discoloration of white fish muscle during frozen storage, and attributed it to oxidative deterioration of unsaturated fish lipids. This is a particularly interesting system in which to study browning reactions, since fish lipids contain large quantities of highly unsaturated lipids and considerable amounts of protein rich in basic amino acids. The oxidation of lipid produces carbonyl compounds, which readily react with the free amino groups to produce browning (Gillatt and Rossell, 1992). In addition, there is clear evidence that the rancid flavor that occurs in oils is due to the decomposition of lipid hydroperoxides to produce aldehydes and ketones. Furthermore, if rancid oils are treated with amino acids, off-flavors and odors are eliminated. Thus, Yamamoto and Kogure (1969) succeeded in removing the rancid odor from fat following its treatment with lysine. Okumura and Kawai (1970) also prepared odor-free oils by reaction with amino acids. Additionally, in mixtures of aldehydes and proteins, the typical off-flavor odor characteristic of rancid fats gradually disappeared on storage and new odor compounds were formed, which produced stale, gluey or even fishy odor notes (Gillatt and Rossell, 1992; Pokorny, 1981). All these effects are only some examples of reactions between oxidized lipids and proteins produced in foods.

Nonenzymatic browning has also been known to be produced in vivo since the discovery of pigment granules, which were reported even before that the cell theory were articulated by Rudolph Virchow in 1858 (Hannover, 1842). Accumulation of yellow-brown lipofuscins, which may occupy up to $40 \%$ of the cytoplasmic volume in postmitotic cells of old animals and that primarily emit yellowish fluorescence when excited with UV or blue light, is regarded as a hallmark of age. They mainly accumulate in postmitotic cells, such as neurons, cardiac muscle, and retinal pigment epithelium. In addition, a similar pigment, named ceroid, is found in cells with mitotic capacity, such as hepatocytes, smooth muscle cells, and a variety of cells of different organs (Strehler, 1977). The basic formation mechanisms of both lipofuscin and ceroid are believed to be the same. The difference is that ceroid forms rapidly during any period in the life of any tissue, whereas lipofuscin accumulates only slowly within postmitotic cells and is more resistant to digestion (Porta, 1991). Although the mechanisms by which such pigments are formed are unknown at present, they are mostly believed to be a consequence of carbonyl/amine reactions (Chio and Tappel, 1969; Desay and Tappel, 1963; Hidalgo and Zamora, 1993a; Yin et al. 1995; Yin, 1996), among which oxidized lipid/protein reactions play a significant role.

\subsection{Oxidized lipid/protein reactions}

The interaction between oxidized lipids and amino acids and proteins is complex indeed, in part as a consequence of the contribution of both lipid hydroperoxide and its secondary products. This interaction may imply either the formation of physical complexes between the oxidized lipids and the protein or the formation of various types of covalent bonds, in addition to the production of protein radicals (Gardner, 1979). Protein polymerizarion produced by reaction with peroxy free radicals generated during lipid peroxidation is known to occur during nonenzymatic browning (Gardner, 1979; Karel et al., 1975; Kikugawa et al., 1990; Neukom, 1980; Schaich, 1980), but its discussion is out of the scope of the present review.

When proteins are exposed to peroxidized lipids, a large proportion of the lipids complex with the 
protein through hydrophobic association and/or hydrogen bonds. The strength of these lipid-protein complexes can be defined by a series of extraction steps, and complexes may be broken with urea/ sodium dodecyl sulfate (Kanazawa et al., 1975; Kanner and Karel, 1976). Although most of the peroxidized lipid usually can be removed from protein by methods that disrupt hydrogen bonds, the lipid resistive to these methods can be separated only after chemical treatment and it is likely to be bound mainly by covalent bonds.

The formation of covalent bonds in the reaction of oxidized lipids with proteins is believed to take place mainly by reaction of the reactive groups of amino acid residues with the secondary products of lipid peroxidation. "Secondary product» is a generic term used to describe a mixture of aldehydes, epoxides, ketones, and other products obtained from the decomposition of lipid hydroperoxides. Although it is not widely recognized, this decomposition does not necessarily imply the breakage of the lipid chain, and the formation of covalent bonds in the reaction between long chain oxidized lipids and amino acids and proteins has been described (Gardner et al., 1976; Gardner et al., 1977; Hidalgo and Zamora, 1995a; Zamora et al., 1987).

The first secondary product related with the formation of lipofuscins and nonenzymatic browning was the malondialdehyde. Because of the bifunctionality of this aldehyde, cross-linking between free amino groups of proteins is possible. Andrews et al. (1965) demonstrated that mixtures of gelatin and peroxidized methyl linoleate led to cross-linked gelatin. Bisulfite, which forms adducts with aldehydes, prevented the cross-links. This cross-link was defined by Chio and Tappel (1969) as a Schiff base conjugate between malondialdehyde and two amino groups producing an $N, N^{\prime}$-disubstituted 1-amino-3-iminopropene. Although nowadays other aldehydes have also been shown to produce lipofuscin-like fluorophores and to be involved in nonenzymatic browning, this and other pioneering papers of Tappel's group were the first approach to try to understand the complexes reactions involved in lipofuscin and nonenzymatic browning production, and they first demonstrated the role of oxidized lipids in these reactions.

\subsection{Mechanism of production of nonenzymatic browning by oxidized lipid/protein reactions}

Analogously to the Maillard reaction, oxidized lipid/ protein reactions also embraces a whole network of different reactions. This is a consequence of the existence of several fatty acids that produce a complex and diverse mixture of lipid oxidation products that are able to react with the different reactive protein residues. To date, only some reaction products have been isolated and identified. These products are preponderantly those that are stable and have not undergone further change to any extent either in the reaction mixture or during isolation or purification. However, difficulties are encountered in the isolation of reactive intermediates, since they are present only in very low concentrations in the reaction mixture and they usually react further during isolation. But these compounds are precisely of the greatest significance for these reactions, because they play an important role in the formation of browning products, aroma compounds, high molecular weight substances, and so on.

Nowadays nonzymatic browning by oxidized lipid/protein reactions is supposed to be a consequence of both the formation of colored low molecular weight compounds and the production of high molecular weight polymers, but at present there is not any quantitative data on the relative contribution of both types of products.

The first mechanism described for nonenzymatic browning was a repeated aldol condensation (Figure 4). Since Mohammad et al. (1949) discovered that acetaldehyde caused protein browning, it has been theorized that Schiff base adducts lead to brown pigments. According to this, the carbonyl compounds derived from unsaturated lipids readily condense with protein-free amino groups to produce imino Schiff bases. Then, Schiff bases polymerize by aldol condensation producing dimers and complex high-molecular weight brown macromolecules. These polymeric brown materials are unstable and generate new volatiles by scission of the macromolecule or dehydration, that affect the flavor characteristic of foods during cooking and processing. In addition, the amino compound even may cleave from the polymer, which may be one of the reasons for the broad range of nitrogen content observed in the polymer (Belitz and Grosch, 1999; Gardner, 1979; Montgomery and Day, 1965).

An additional mechanism for the formation of nonenzymatic brown polymers was proposed much more recently. It is based on the polymerization of other reactive intermediates: the 2-(1-hydroxyalkyl)pyrroles. These compounds are produced in the reaction of epoxyalkenals and unsaturated epoxyketo fatty acids with amines, amino acids and proteins (Hidalgo and Zamora, 1995a, 1995c; Zamora and Hidalgo, 1994, 1995b). As an additional product, these reactions also produce the more stable 1-alkylpyrroles, which have been found in numerous fresh food products and have been shown to be produced as a consequence of oxidative stress (Hidalgo et al., 1998; Zamora et al., 1995, 1999a). The polymerization of 2-(1-hydroxyalkyl)pyrroles takes 
$\mathrm{R}_{1} \mathrm{CH}_{2} \mathrm{CHO}$

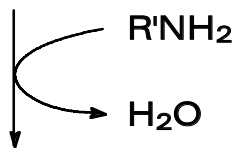

$\mathrm{R}_{1} \mathrm{CH}_{2} \mathrm{CH}=\mathrm{N}-\mathrm{R}^{\prime}$
$\longrightarrow \mathrm{H}_{2} \mathrm{O}$

$\mathrm{R}_{2} \mathrm{CH}=\stackrel{\mathrm{R}_{1}}{\mathrm{l}} \mathrm{C}-\mathrm{CH}=\mathrm{N}-\mathrm{R}^{\prime}$

$\mathrm{H}_{2} \mathrm{O} \quad \mathrm{R}^{\prime} \mathrm{NH}_{2}$

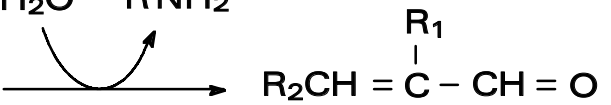

repeated

aldol

condensations

\section{Brown pigments}

Figure 4

Formation of brown pigments by aldolic condensation

place spontaneously and the formation of dimers, trimers, tetramers and higher polymers were detected by different techniques, which included nuclear magnetic reasonance spectroscopy, mass spectrometry, and gel filtration chromatography (Hidalgo and Zamora, 1993a). The route of formation of this polymer and, in general, the different reactions produced as a consequence of the reaction of epoxyalkenals and unsaturated epoxyketo fatty acids with the reactive groups of proteins are given in the Figure 5.

The formation of this polypyrrolic polymer gave a satisfactory explanation for the color and fluorescence produced in these reactions (Hidalgo and Zamora, 1993b, 1995b; Hidalgo et al., 1999; Zamora and Hidalgo, 1992, 1995a) as well as the formation of short chain aldehydes and volatile heterocyclic compounds (Zamora and Hidalgo, 1995b; Zamora et al., 1994). However, it does not explain some findings of melanoidins with a low nitrogen content. It might be a consequence of either the difficulty of purifying melanoidins, which may be contaminated by low molecular weight monomers or by other polymers produced exclusively by polymerization of unsaturated fatty acids (see above), or that the melanoidins are not a homogeneous polymer but a mixture of different polymers produced by different mechanisms. According to our present knowledge, both possibilities are likely occuring. In this context, the recent appearance of a new method to determine pyrrolized proteins may help to study the presence of polypyrrolic structures in melanoidins (Hidalgo et al., 1998).

In addition to these polymeric structures, the formation of low molecular weight monomers by oxidized lipid/protein reactions has also been shown to contribute to the color and/or fluorescence of nonenzymatic browning reactions. During the last three decades numerous compounds have been isolated, mostly by studying model reactions and using different oxidized lipids. In the present review, an attempt to describe only the oxidized lipids that contributes most clearly to the color and/or fluorescence has been made. Consequently the results of some studies are not or only partly taken into account, without any intention of detracting from their importance.

One of the oxidized lipids that has been more intensely studied in the last decades has been the malondialdehyde. This compound has been described to produce conjugated Schiff bases by Tappel's group (see above), but also fluorescent dihydropyridines, among other compounds (Gómez-Sánchez et al., 1990; Itakura et al., 1996; 


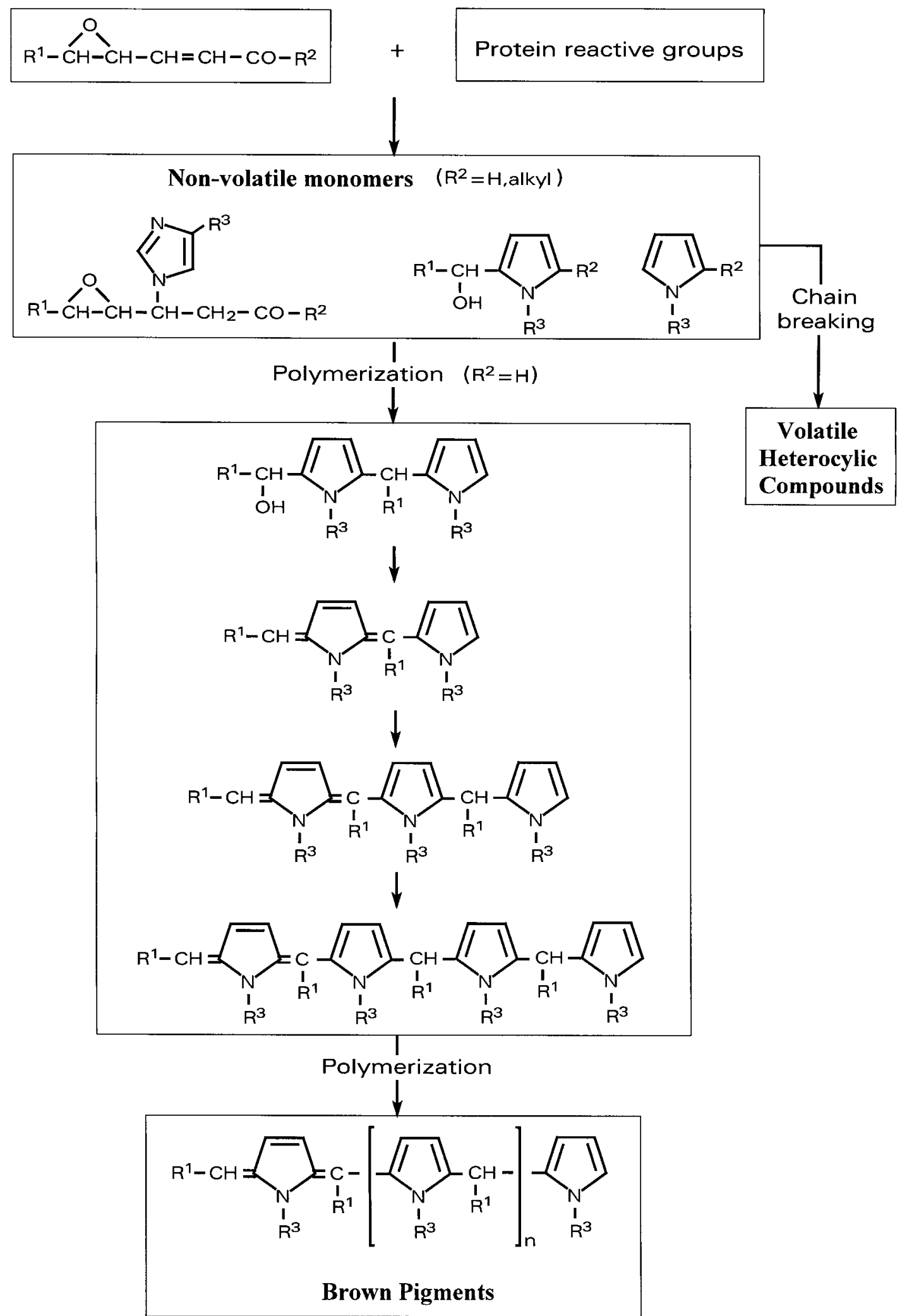

Figure 5

The epoxyketopentene/protein reaction pathway 
Kikugawa and Ido, 1984; Nair et al., 1986, 1988). Malondialdehyde has also been implicated in the formation of pyridinium salts (Itakura et al., 1996), which were previously supposed to be produced only by reaction of alkanals or 2-alkenals (Alaiz and Barragán, 1994; Suyama and Adachi, 1979).

In addition to malondialdehyde, the other group of oxidized lipids that has attracted much attention has been the 4-hydroxyalkenals. These compounds are known to produce nonenzymatic browning and fluorescence and they have been shown to react mostly via Michael additions with the reactive groups of amino acids and proteins, although the formation of pyrrole derivatives has also been described (Baker et al., 1998; Esterbauer et al., 1990, 1991; Nadkarni and Sayre, 1995; Sayre et al., 1993; Szweda et al., 1993; Xu and Sayre, 1998).

Other short chain aldehydes have also been related to the formation of low molecular weight oxidized lipid/amino acid reaction products that either are colored or are suspicious to contribute to the nonenzymatic browning produced by reaction with amines, amino acid and proteins. Among these compounds, the most clearly related are the above discussed 4,5-epoxy-2-alkenals that produces pyrroles or Michael adducts and react with proteins according to the pathway shown in Figure 5 (Zamora and Hidalgo, 1994; Zamora et al., 1999b). Other studied lipid oxidation products are: 2alkenals (Alaiz and Barragán, 1994; Alaiz and Girón, 1994), 2,4-decadienal (Leake and Karel, 1985), 3-(2-ethyl-5-hydroxy-3-oxo-cyclopentyl)-2propenal (Nakamura, 1985; Nakamura et al., 1998), 4,5-epoxy-2-alkenols (Lederer, 1996), and hexanal (Kaneko et al., 1991).

\section{FUTURE TRENDS}

Although almost 90 years have passed since the first research on the Maillard reaction, and more that 150 years since the first observation of lipofuscins, it is still not possible to present a complete reaction scheme of these and other similar reactions. The above described studies on the origin of both melanoidins and lipofuscins suggest that the thermodynamically favored, time-dependent, carbonyl-protein crosslinking reactions are the most likely mechanism, at least as an initial step, which may be followed by a pyrrole polymerization, as determined for both oxidized lipid/protein reactions and the Maillard reaction. Therefore, the role of lipids in these reactions does not seem to be very different to the role of carbohydrates in the Maillard reaction or the phenols in the enzymatic browning. These carbonyl-amine reactions seem to be a group of gradual, partially reversible, universal, and inevitable side reactions in both food and biological systems. In addition, they may be also a protective mechanism by which endogenous antioxidants are generated (Alaiz et al. 1995, 1996b; Hayase, 1996; Zamora et al., 1997).

However, most of the results presented above have been obtained from studies carried out with model systems, in which the different types of nonenzymatic browning were produced in the absence of the others. Future studies should afford systems closer to real foods or living beings, by studying, for example, the influence of lipid oxidation in the melanoidins produced by the Maillard reaction and vice versa. Some of these studies have begun to appear with interesting results (Alaiz et al., 1997b, 1999; Baynes, 1996; Degenhardt et al., 1998; Fu et al., 1996; Hidalgo et al., 1999; Mottram and Elmore, 1998). In addition, the use of better techniques to isolate and characterize melanoidins would also be desirable. Most of the discrepancies observed for the different melanoidins studied might be the consequence, at least partially, of a lack of purity of these polymeric compounds that may absorb different monomers as well as other polymers.

Are similar melanoidins produced by different nonenzymatic browning reactions? Although, a priori, melanoidins obtained from sugars and oxidized lipids should be different, the recent studies of Tressl et al. (1998a, 1998b), Hidalgo and Zamora (1993a), and Hidalgo et al. (1999), have demonstrated that it is possible to obtain the same, or very similar, polymers starting from both oxidized lipids and carbohydrates. To confirm this hypothesis in systems closer to real foods, new methods should be developed that allow either to fractionate melanoidins or to study the groups present in them. Promising methods in these studies may be the determination of protein carbonylation (Levine et al., 1990) and/or protein pyrrolization (Hidalgo et al., 1998).

Finally, future trends should also include studies on the recognition and degradation of nonenzymatic reaction products in biological systems as well as continued studies on the design and evaluation of inhibitors of the nonenzymatic browning in biological systems for therapeutic intervention in the progress of diseases, continuing some of the studies already carried out (Horie et al., 1997; Ulrich, 1998; Vasan et al., 1996).

All these studies should provide a more complete understanding of nonenzymatic browning, and, therefore, to afford a much more comprehensive knowledge of food and human biochemistry.

\section{ACKNOWLEDGMENTS}

This study was supported in part by the Comisión Interministerial de Ciencia y Tecnología of Spain (Project ALI97-0358) and the Junta de 
Andalucía (Project AGR 0135). We are indebted to Mr. J. L. Navarro and Mrs. M. D. García for the technical assistance.

\section{BIBLIOGRAPHY}

Acton, J. C., and Dawson, P. L. (1994). Color as a Functional Property of Proteins in Protein Functionality in Food Systems, pp. 357-381, N. S. Hettiarachchy and G. R. Ziegler (Eds.), Marcel Dekker, New York.

Adhikari, H. R., and Tappel, A. L. (1973). Fluorescent Products in a Glucose-Glycine Browning Reaction. $J$. Food Sci., 38, 486-488.

Ahmad, I., Alaiz, M., Zamora, R., and Hidalgo, F. J. (1998). Effect of Oxidized Lipid/Amino Acid Reaction Products on the Antioxidative Activity of Common Antioxidants. J. Agric. Food Chem., 46, 3768-3771.

Alaiz, M., and Barragán, M. (1994). Reaction of a Lysyl Residue Analogue with (E)-2-Octenal. Chem. Phys. Lipids, 75, 43-49.

Alaiz, M., and Girón, J. (1994). Reaction of N(carbobenzyloxy)-L-histidine with (E)-2-octenal. Chem. Phys. Lipids, 71, 245-248.

Alaiz, M., Zamora, R., and Hidalgo, F. J. (1995). Natural Antioxidants Produced in Oxidized Lipid/Amino Acid Browning Reactions. J. Am. Oil Chem. Soc., 72, 15711575.

Alaiz, M., Zamora, R., and Hidalgo, F. J. (1996a). Antioxidative Activity of Pyrrole, Imidazole, Dihydropyridine, and Pyridinium Salt Derivatives Produced in Oxidized Lipid/Amino Acid Browning Reactions. J. Agric. Food Chem., 44, 686-691.

Alaiz, M., Zamora, R., and Hidalgo, F. J. (1996b). Contribution of the Formation of Oxidized Lipid/Amino Acid Reaction Products to the Protective Role of Amino Acids in Oils and Fats. J. Agric. Food Chem., 44, 1890-1895.

Alaiz, M., Hidalgo, F. J., and Zamora, R. (1997a). Antioxidative Activity of Nonenzymatically Browned Proteins Produced in Oxidized Lipid/Protein Reactions. J. Agric. Food Chem., 45, 1365-1369.

Alaiz, M., Hidalgo, F. J., and Zamora, R. (1997b). Comparative Antioxidant Activity of Maillard and Oxidized Lipid-Damaged Bovine Serum Albumin. J. Agric. Food Chem., 45, 3250-3254.

Alaiz, M., Hidalgo, F. J., and Zamora, R. (1999). Effect of $\mathrm{pH}$ and Temperature on Comparative Antioxidant Activity of Nonenzymatically Browned Proteins Produced by Reaction with Oxidized Lipids and Carbohydrates. J. Agric. Food Chem., 47, 748-752.

Andrews, F., Bjorksten, J., Trenk, F. B., Henick, A. S., and Koch, R. B. (1965). The Reaction of an Autoxidized Lipid with Proteins. J. Am. Oil Chem. Soc., 42, 779-781.

Arnoldi, A., Arnoldi, C., Baldi, O., and Ghizzoni, C. (1990). Effect of Lipids in the Maillard Reaction in The Maillard Reaction in Food Processing, Human Nutrition and Physiology, pp. 133-138, P. A. Finot, H. U. Aeschbacher, R. F. Hurrell, and R. Liardon (Eds.), Birkhäuser Verlag, Basel, Switzerland.

Arnoldi, A., Corain, E. A., Scaglioni, L., and Ames, J. M. (1997). New Colored Compounds from the Maillard Reaction Between Xylose and Lysine. J. Agric. Food Chem., 45, 650-655.
Aubourg, S. (1998). Detección de Fluorescencia en Sistemas Modelo Conteniendo Aldehidos: Relación con la Alteración del Pescado. Grasas Aceites, 49, 419-424.

Baker, A., Zidek, L., Wiesler, D., Chmelik, J., Pagel, M., and Novotny, M. V. (1998). Reaction of $\mathrm{N}$-acetylglycyllysine Methyl Ester with 2-Alkenals: An Alternative Model for Covalent Modification of Proteins. Chem. Res. Toxicol., 11, 730-740.

Baynes, J. W. (1996). The Role of Oxidation in the Maillard Reaction in vivo in The Maillard Reaction. Consequences for the Chemical and Life Sciences, pp. 55-72, R. Ikan (Ed.), John Wiley, Chichester, England.

Belitz, H.-D., and Grosch, W. (1999). Food Chemistry, 2nd Ed., Springer, Berlin.

Benzing-Purdie, L. M., and Ratcliffe, C. I. (1986). A Study of the Maillard Reaction by ${ }^{13} \mathrm{C}$ and ${ }^{15} \mathrm{~N}$ CP-MAS NMR: Influence of Time, Temperature, and Reactants on Mayor Products. Dev. Food Sci., 13, 193-205.

Berdeaux, O., Márquez-Ruiz, G., and Dobarganes, M. C. (1999). Characterization, Quantitation and Evolution of Monoepoxy Compounds Formed in Model Systems of Fatty Acid Methyl Esters and Monoacid Triglycerides Heated at High Temperature. Grasas Aceites, 50, 53-59.

Boileau, T. W. M., Moore, A. C., and Erdman, J. W. (1999). Carotenoids and Vitamin A in Antioxidant Status, Diet, Nutrition, and Health, pp. 133-158, A. M. Papas (Ed.), CRC Press, Boca Raton, Florida.

Buttkus, H. A. (1975). Fluorescent Lipid Autoxidation Products. J. Am. Oil Chem. Soc., 23, 823-825.

Chio, K. S., and Tappel, A. L. (1969). Synthesis and Characterization of the Fluorescent Products Derived from Malonaldehyde and Amino Acids. Biochemistry, 8, 2821-2827.

Clydesdale, F. M. (1988). Color: Origin, Stability, Measurement, and Quality in Food Storage Stability, pp. 175-190, I. A. Taub and R. P. Singh (Eds.), CRC Press, Boca Raton, Florida.

Danehy, J. P. (1986). Maillard Reactions: Nonenzymatic Browning in Food Systems with Special Reference to the Development of Flavor. Adv. Food Res., 30, 77-138.

Degenhardt, T. P., Brinkmann-Frye, E., Thorpe, S. R., and Baynes, J. W. (1998). Role of Carbonyl Stress in Aging and Age-Related Diseases in The Maillard Reaction in Foods and Medicine, pp. 3-10, J. O'Brien, H. E. Nursten, M. J. C. Crabbe, and J. M. Ames (Eds.), The Royal Society of Chemistry, Cambridge, England.

Desai, I. D., and Tappel, A. L. (1963). Damage to Proteins by Peroxidized Lipids. J. Lipid Res., 4, 204-207.

Deyl, Z., and Miksik, I. (1997). Post-translational Non-enzymatic Modification of Proteins. I. Chromatography of Marker Adducts with Special Emphasis to Glycation Reactions. J. Chromatogr., 699B, 287-309.

von Elbe, J. H., and Schwartz, S. J. (1996). Colorants in Food Chemistry, 3rd Ed., pp. 651-722, O. R. Fennema (Ed.), Marcel Dekker, New York.

El-Zeany, B. A., and Fattah, L. E. A. (1982). Oxidised Lipids-Proteins Browning Reaction. Part 6. Browning Produced by the Interaction of Free Fatty Acids with Proteins. Grasas Aceites, 33, 216-219.

Esterbauer, H., Zollner, H., and Schaur, R. J. (1990). Aldehydes Formed by Lipid Peroxidation: Mechanisms of Formation, Occurence, and Determination in 
Membrane Lipid Oxidation, Vol. I, pp. 239-268, C. Vigo-Pelfrey (Ed.), CRC Press, Boca Raton, Florida.

Esterbauer, H., Schaur, R. J., and Zollner, H. (1991). Chemistry and Biochemistry of 4-Hydroxynonenal, Malonaldehyde and Related Aldehydes. Free Radical Biol. Med., 11, 81-128.

Eskin, N. A. M. (1990). Biochemistry of Foods, 2nd Ed., Academic Press, New York.

Feather, M. S., and Huang, R. D. (1986). Some Studies on a Maillard Polymer Derived from L-Alanine and DGlucose. Dev. Food Sci., 13, 183-192.

Feinberg, B., Olson, R. L., and Mullins, W. R. (1987). Prepeeled Potatoes in Potato Processing, $4^{\text {th }}$ Ed., pp. 697-726, W. F. Talburt and O. Smith (Eds.), AVI-van Nostrand Reinhold, New York.

Finot, P. A. (1997). Effects of Processing and Storage on the Nutritional Value of Food Proteins in Food Proteins and Their Applications, pp. 551-577, S. Damoradan and A. Paraf (Eds.), Marcel Dekker, New York.

Francis, F. J. (1985). Pigments and Other Colorants in Food Chemistry, 2nd Ed., pp. 545-584, O. R. Fennema (Ed.), Marcel Dekker, New York.

Francis, F. J. (1993). Colorimetry of Foods in Physical Properties of Foods, pp. 105-123, M. Peleg and E. B. Bagley (Eds.), AVI Publishing, Westport, Connecticut.

Francis, F. J. (1999). Colorants, Eagan Press, St. Paul, Minnesota.

Franke, C., and Iwainsky, H. (1954). Zur Antioxidativen Wirksamkeit der Melanoidine. Dtsch. Lebensm. Rundsch., 50, 251-254.

Frankel, E. N. (1998). Lipid Oxidation, The Oily Press, Dundee, Scotland.

Friedman, M. (1996). Food Browning and its Prevention: An Overview. J. Agric. Food Chem., 44, 631-653.

Fu, M., Requena, J. R., Jenkins, A. J., Lyons, T. J., Baynes, J. W., and Thorpe, S. R. (1996). The Advanced Glycation End-product, $N \varepsilon$-(Carboxymethyl)lysine $(\mathrm{CML})$, is a Product of Both Lipid Peroxidation and Glycoxidation Reactions. J. Biol. Chem., 271, 99829986.

Gardner, H. W. (1975). Decomposition of Linoleic Acid Hydroperoxides. Enzymatic Reactions Compared with Nonenzymatic. J. Agric. Food Chem., 23, 129-136.

Gardner, H. W. (1979). Lipid Hydroperoxide Reactivity with Proteins and Amino Acids: A Review. J. Agric. Food Chem., 27, 220-229.

Gardner, H. W. (1980). Lipid Enzymes: Lipases, Lipoxygesases and Hydroperoxides in Autoxidation in Food and Biological Systems, pp. 447-504, M. G. Simic and M. Karel (Eds.), Plenum Press, New York.

Gardner, H. W. (1985). Oxidation of Lipids in Biological Tissue and its Significance in Chemical Changes in Food During Processing, pp. 177-203, T. Richardson and J. W. Finley (Eds.), AVI Publishing, Westport, Connecticut.

Gardner, H. W. (1989). Oxygen Radical Chemistry of Polyunsaturated Fatty Acids. Free Radical Biol. Med., 7, 65-86.

Gardner, H. W. (1997). Analysis of Plant Lipoxygenase Metabolites in Advances in Lipid Methodology-Four, pp. 1-43, W. W. Christie (Ed.), The Oily Press, Dundee, Scotland.

Gardner, H. W., Weisleder, D., and Kleiman, R. (1976). Addition of $\mathrm{N}$-Acetylcysteine to Linoleic Acid Hydroperoxide. Lipids, 11, 127-134.
Gardner, H. W., Kleiman, R., Weisleder, D., and Inglett, G. E. (1977). Cysteine Adds to Lipid Hydroperoxide. Lipids, 12, 655-660.

Gasparoli, A., (1998). The Formation of New Compounds. Grasas Aceites, 49, 303-309.

Ghorpade, V. M., Deshpande, S. S., and Salunkhe, D. K. (1995). Food Colors in Food Additive Toxicology, pp. 179-233, J. A. Maga and A. T. Tu (Eds.), Marcel Dekker, New York.

Gillatt, P. N., and Rossell, J. B. (1992). The Interaction of Oxidized Lipids with Proteins in Advances in Applied Lipid Research, pp. 65-118, F. B. Padley (Ed.), JAI Press, Greenwich, Connecticut.

Gómez-Sánchez, A., Hermosín, I., and Maya, I. (1990). Heterocycle Formation from Malondialdehyde and Amino Sugars in The Maillard Reaction in Food Processing, Human Nutrition and Physiology, pp. 139144, P. A. Finot, H. U. Aesbacher, R. F. Hurrell, and R. Liardon (Eds.), Birkhäuser Verlag, Basel, Switzerland.

Gregory, J. F. (1996). Vitamins in Food Chemistry, 3rd Ed., pp. 531-616, O. R. Fennema (Ed.), Marcel Dekker, New York.

Grechkin, A. (1998). Recent Developments in Biochemistry of the Plant Lipoxygenase Pathway. Prog. Lipid Res., 37, 317-352.

Haard, N. F. (1992). Biochemistry and Chemistry of Color and Color Change in Seafoods in Advances in Seafood Biochemistry, Composition and Quality, pp. 305-360, G. J. Flick Jr. and R. E. Martin (Eds.), Technomic Publishing Co., Lancaster, Pennsylvania.

Haard, N. F. (1998). Foods as Cellular Systems: Impact on Quality and Preservation in Food Storage Stability, pp. 39-74, I. A. Taub and R. P. Singh (Eds.), CRC Press, Boca Raton, Florida.

Haard, N. F., and Chism, G. W. (1996). Characteristics of Edible Plant Tissues in Food Chemistry, 3rd Ed., pp. 943-1011, O. R. Fennema (Ed.), Marcel Dekker, New York.

Handwerk, R. L., and Coleman, R. L. (1988). Approaches to the Citrus Browning Problem. A Review. J. Agric. Food Chem., 36, 231-236.

Hannover, A. (1842). Mikroskopishe Undersogelser af Nevensystem. Nattruv. Math. Afh. Copenhagen, 10, 1-112.

Hashiba, H. (1986). Oxidative Browning of Amadori Compounds. Color Formation by Iron with Maillard Reaction Products. Dev. Food Sci., 13, 155-164.

Hayase, F. (1996). Scavenging of Active Oxygen by Melanoidins in The Maillard Reaction. Consequences for the Chemical and Life Sciences, pp. 89-104, R. Ikan (Ed.), John Wiley, Chichester, England.

Hendrich, S., Wang, G.-J., Lin, H.-K., Xu, X., Tew, B.-Y., Wang, H.-J., and Murphy, P. A. (1999). Isoflavone Metabolism and Bioavailability in Antioxidant Status, Diet, Nutrition, and Health, pp. 211-230, A. M. Papas (Ed.), CRC Press, Boca Raton, Florida.

Hendry, G. A. F., and Houghton, J. D. (Eds.) (1996). Natural Food Colorants, $2^{\text {nd }}$ Ed., Blackie, London.

Heyns, K., and Klier, A. (1968). Fragmentierungen von Kohlenhydraten. Carbohydr. Res., 6, 436-448.

Hidalgo, F. J., and Zamora, R. (1993a). Fluorescent Pyrrole Products from Carbonyl-Amine Reactions. J. Biol. Chem., 268, 16190-16197.

Hidalgo, F. J., and Zamora, R. (1993b). Non-Enzymatic Browning and Fluorescence Development in a $(E)$ - 
4,5-Epoxy-(E)-2-heptenal/Lysine Model System. J. Food Sci., 58, 667-670.

Hidalgo, F. J., and Zamora, R. (1995a). In Vitro Production of Long Chain Pyrrole Fatty Esters from CarbonylAmine Reactions. J. Lipid Res., 36, 725-735.

Hidalgo, F. J., and Zamora, R. (1995b). Characterization of the Products Formed during Microwave Irradiation of the Nonenzymatic Browning Lysine/(E)-4,5-Epoxy(E)-2-heptenal Model System. J. Agric. Food Chem., 43, 1023-1028.

Hidalgo, F. J., and Zamora, R. (1995c). Epoxyoxoene Fatty Esters: Key Intermediates for the Synthesis of Long-Chain Pyrrole and Furan Fatty Esters. Chem. Phys. Lipids, 77, 1-11.

Hidalgo, F. J., Zamora, R., and Alaiz, M. (1991). Modificaciones Producidas en las Proteínas Alimentarias por su Interacción con Lípidos Peroxidados. I. Química Radicalaria de los Ácidos Grasos Poliinsaturados. Grasas Aceites, 42, 379-386.

Hidalgo, F. J., Zamora, R., and Alaiz, M. (1992). Modificaciones Producidas en las Proteínas Alimentarias por su Interacción con Lípidos Peroxidados. II. Mecanismos Conocidos de la Interacción Lípido (Oxidado)Proteína. Grasas Aceites, 43, 31-38.

Hidalgo, F. J., Alaiz, M., and Zamora, R. (1998). A Spectrophotometric Method for the Determination of Proteins Damaged by Oxidized Lipids. Anal. Biochem., 262, 129-136.

Hidalgo, F. J., Alaiz, M., and Zamora, R. (1999). Effect of $\mathrm{pH}$ and Temperature on Comparative Nonenzymatic Browning of Proteins Produced by Oxidized Lipids and Carbohydrates. J. Agric. Food Chem., 47, 742747.

Hodge, J. E. (1953). Dehydrated Foods. Chemistry of Browning Reactions in Model Systems. J. Agric. Food Chem., 1, 928-943.

Hofmann, T. (1998). Determination of the Chemical Structure of Novel Coloured Compounds Generated during Maillard-type Reactions in The Maillard Reaction in Foods and Medicine, pp. 82-88, J. O'Brien, H. E. Nursten, M. J. C. Crabbe, and J. M. Ames (Eds.), The Royal Society of Chemistry, Cambridge.

Horie, K., Miyata, T., Maeda, K., Miyata, S., Sugiyama, S., Sakai, H., Strihou, C. Y., Monnier, V. M., Witztum, J. L., and Kurokawa, K. (1997). Immunohistochemical Colocalization of Glycoxidation Products and Lipid Peroxidation Products in Diabetic Renal Glomerular Lesions. Implication for Glycoxidative Stress in the Pathogenesis of Diabetic Nephropathy. J. Clin. Invest., 100, 2995-3004.

Huang, R. D., and Feather, M. S. (1988). ${ }^{13} \mathrm{C}$ NMR Study of Some Maillard Reaction Products Arising from DGlucose-DL-Alanine Interactions. J. Agric. Food Chem., 36, 673-676.

Hurrell, R. F., and Finot, P. A. (1985). Effects of Food Processing on Protein Digestibility and Amino Acid Availability in Digestibility and Amino Acid Availability in Cereals and Oilseeds, pp. 233-246, J. W. Finley and D. T. Hopkins (Eds.), American Association of Cereal Chemists, St. Paul, Minnesota.

Hurst, D. T. (1972). Recent Developments in the Study of Nonenzymic Browning and its Inhibition by Sulphur Dioxide, BFMIRA Scientific and Technical Surveys No. 75, Leatherhead, England.

Hutchings, J. B. (1994). Food Color and Appearance, Blackie, Glasgow.
Ikan, R (Ed.) (1996). The Maillard Reaction. Consequences for the Chemical and Life Science, John Wiley, New York.

Itakura, K., Uchida, K., and Osawa, T. (1996). A Novel Fluorescent Malondialdehyde-lysine Adduct. Chem. Phys. Lipids, 84, 75-79.

Kacem, B., Cornell, J. A., Marshall, M. R., Shireman, R. B., and Matthews, R. F. (1987). Nonenzymatic Browning in Aseptically Packaged Orange Drinks: Effect of Ascorbic Acid, Amino Acids and Oxygen. J. Food Sci., 52, 1668-1672.

Kamal-Eldin, A., and Appelqvist, L.-Å. (1996). Aldehydic Acids in Frying Oils: Formation, Toxicological Significance and Analysis. Grasas Aceites, 47, 342-348.

Kanazawa, K., Danno, G., and Natake, M. (1975). Lysozyme Damage Caused by Secondary Degradation Products During the Autoxidation Process of Linoleic Acid. J. Nutr. Sci. Vitaminol., 21, 373-382.

Kaneko, S., Okitani, A., Hayase, F., and Kato, H. (1991). Identification of an Intermediate Product and Formation Mechanisms of Cross-linking Compounds from $N \alpha$-Acetyltryptophan and Hexanal. Agric. Biol. Chem., 55, 723-730.

Kanner, J., and Karel, M. (1976). Changes in Lysozyme due to Reactions with Peroxidizing Methyl Linoleate in Dehydrated Model System. J. Agric. Food Chem., 24, 468-472.

Karel, M. (1992). Kinetics of Lipid Oxidation in Physical Chemistry of Foods, pp. 651-668, H. G. Schwartzberg and R. W. Hartel (Eds.), Marcel Dekker, New York.

Karel, M., Schaich, K., and Roy, R. B. (1975). Interaction of Peroxidizing Methyl Linoleate with Some Proteins and Amino Acids. J. Agric. Food Chem., 23, 159-163.

Kato, H., and Tsuchida, H. (1981). Estimation of Melanoidin Structure by Pyrolysis and Oxidation. Prog. Food Nutr. Sci., 5, 147-156.

Kato, H., Kim, S. B., and Hayase, F. (1986). Estimation of the Partial Chemical Structure of Melanoidins by Oxidative Degradation and ${ }^{13} \mathrm{C}$ CP-MAS NMR. Dev. Food Sci., 13, 215-223.

Khayat, A., and Schwall, D. (1983). Lipid Oxidation in Seafood. Food Tecnol., 37 (7), 130-140.

Kikugawa, K., and Ido, Y. (1984). Studies on Peroxidized Lipids. V. Formation and Characterization of 1 , 4-Dihydropyridine-3,5-dicarbaldehydes as Model of Fluorescent Components in Lipofuscin. Lipids, 19, 600-608.

Kikugawa, K., Kato, T., Beppu, M., and Hayasaka, A. (1990). Fluorescent and Cross-linked Proteins Formed by Free Radical and Aldehyde Species Generated During Lipid Oxidation in Lipofuscin and Ceroid Pigments, pp. 345-357, E. A. Porta, Plenum Press, New York.

Labuza, T. P., and Baisier, W. M. (1992). The Kinetics of Nonenzymatic Browning in Physical Chemistry of Foods, pp. 595-649, H. G. Schwartzberg and R. W. Hartel (Eds.), Marcel Dekker, New York.

Leake, L., and Karel, M. (1985). Nature of Fluorescent Compounds Generated by Exposure of Protein to Oxidizing Lipids. J. Food Biochem., 9, 117-136.

Ledl, F., and Schleicher, E. (1990). New Aspects of the Maillard Reaction in Foods and in the Human Body. Angew. Chem. Int. Ed. Engl., 29, 565-706.

Ledl, F., and Severin, T. H. (1981). Investigation of a Xilose- and Glucose-Methylammonium Acetate Reaction Mixture. Prog. Food Nutr. Sci., 5, 65-69. 
Ledl, F., and Severin, T. H. (1982). Formation of Colored Compounds from Hexoses. XVI. Studies Relating to the Maillard Reaction. Z. Lebensm. Unters. Forsch., 175, 262-265.

Ledl, F., Hiebl, J.; and Severin, T. H. (1983). Bildung Jäbiger $\beta$-Pyranone aus Pentosen and Hexosen, $Z$. Lebensm. Unters. Forsch., 177, 353-355.

Lederer, M. O. (1996). Reactivity of Lysine Moieties Toward $\gamma$-Hydroxy- $\alpha, \beta$-unsaturated Epoxides: A Model Study on Protein-Lipid Oxidation Product Interaction. J. Agric. Food Chem., 44, 2531-2537.

Levine, R. L., Garland, D., Oliver, C. N., Amici, A., Climent, I., Lenz, A. G., Ahn, B., Shatiel, S., and Stadtman, E. R. (1990). Determination of Carbonyl Content in Oxidatively Modified Proteins. Methods Enzymol., 186, 464-474.

MacDougall, D. B. (1994). Colour of Meat in Quality Attributes and their Measurement in Meat, Poultry and Fish Products, pp. 79-93, A. M. Pearson and T. R. Dutson (Eds.), Blackie, Glasgow.

deMan, J. M. (1999). Principles of Food Chemistry, 3rd Ed., Aspen Publishers, Gaithersburg, Maryland.

Mauron, J. (1986). Effects of Processing on Proteins in Proceedings of the XIII International Congress of Nutrition, pp. 780-785, T. G. Taylor and N. K. Jenkins (Eds.), John Libbey, London.

Mínguez, M. I., Jarén, M., and Hornero, D. (Eds.) (1999). Pigments in Food Technology, Abstracts of the 1st International Congress on Pigments in Food Technology, Sevilla.

Miquel, J., Oro, J., Bensch, K. G., and Johnson, J. E. (1977). Lipofuscin: Fine-Structural and Biochemical Studies in Free Radicals in Biology, vol. III, pp. 133182, W. A. Pryor (Ed.), Academic Press, New York.

Mohammad, A., Olcott, H. S., and Fraenkel-Conrat, H. (1949). Reaction of Protein with Acetaldehyde. Arch. Biochem., 24, 270-280.

Montgomery, M. W., and Day, E. A. (1965). AldehydeAmine Condensation Reaction: A Possible Fate of Carbonyls in Foods. J. Food Sci., 30, 828-832.

Mottram, D. S., and Elmore, J. S. (1998). The Interaction of Lipid-Derived Aldehydes with the Maillard Reaction in Meat Systems in The Maillard Reaction in Foods and Medicine, pp. 198-203, J. O'Brien, H. E. Nursten, M. J. C. Crabbe, and J. M. Ames (Eds.), The Royal Society of Chemistry, Cambridge, England.

Nadkarni, D. V., and Sayre, L. M. (1995). Structural Definition of Early Lysine and Histidine Adduction Chemistry of 4-Hydroxynonenal. Chem. Res. Toxicol., 8, 284-291.

Nair, V., Offerman, R. J., and Turner, G. A. (1986). Novel Fluorescent 1,4-Dihydropyridines. J. Am. Oil Chem. Soc., 108, 8283-8285.

Nair, V., Offerman, R. J., Tumer, G. A., Pryor, A. N., and Baenziger, N. C. (1988). Fluorescent 1,4-Dihydropyridines: the Malondialdehyde Connection. Tetrahedron, 44, 27932803.

Nakamura, T. (1985). Red Pigment-forming Substances from Autoxidized Linolenate: Identification of Protaglandin-like Substances. Lipids, 20, 180-186.

Nakamura, T., Hama, Y. Tanaka, R., Taira, K., and Hatate, H. (1998). A New Red Coloration Induced by the Reaction of Oxidized Lipids with Amino Acids. J. Agric. Food Chem., 46, 1316-1320.

Namiki, M. (1988). Chemistry of Maillard Reactions: Recent Studies on the Browning Reaction Mechanism and the Development of Antioxidants and Mutagens. Adv. Food Res., 32, 115-184.

Nawar, W. W. (1996). Lipids in Food Chemistry, 3rd Ed., pp. 225-319, O. R. Fennema (Ed.), Marcel Dekker, New York.

Nawar, W. W. (1998). Volatile Components of the Frying Process. Grasas Aceites, 49, 271-274.

Neukom, H. (1980). Oxidative Crosslinking of Proteins and Other Biopolymers in Autoxidation in Food and Biological Systems, pp. 249-259, M. G. Simic and M. Karel (Eds.), Plenum Press, New York.

Nichols, R. (1985). Post-harvest Physiology and Storage in The Biology and Technology of the Cultivated Mushroom, pp. 195-210, P. B. Flegg, D. M. Spencer, and D. A. Wood (Eds.), John Wiley, New York.

Nursten, H. E., and O'Reilly, R. (1983). Colored Compounds Formed by the Interaction of Glycine and Xylose. ACS Symp. Ser., 215, 103-121.

Obretenov, T., and Argirov, O. (1986). Investigation of the Interaction Between Furfural and Glycine Methyl Ester as a Model of Maillard Reaction. Dev. Food Sci., 13, 225-232.

O'Brien, J., Nursten, H. E., Crabbe, M. J. C., and Ames, J. M. (Eds.) (1998). The Maillard Reaction in Foods and Medicine, The Royal Society of Chemistry, Cambridge.

Okumura, S., and Kawai, H. (1970). Amino Acids for Seasoning Food. Japanese Patent 7039622.

Olsson, K., Pernemalm, P. A., and Theander, O. (1981). Reaction Products and Mechanism in Some Simple Model Systems. Progr. Food Nutr. Sci., 5, 47-55.

Osuga, D., van der Schaaf, A., and Whitaker, J. R. (1994). Control of Polyphenol Oxidase Activity Using a Catalytic Mechanism in Protein Structure-Function Relationships in Foods, pp. 62-88, R. Y. Yada, R. L. Jackman, and J. L. Smith (Eds.), Blackie, Glasgow.

Piazza, G. J. (Ed.) (1996). Lipoxygenase and Lipoxygenase Pathway Enzymes, AOCS Press, Champaign, Illinois.

Pischetsrieder, M., Larisch, B., and Severin, T. (1998). The Maillard Reaction of Ascorbic Acid with Amino Acids and Proteins - Identification of Products in The Maillard Reaction in Foods and Medicine, pp. 107112, J. O'Brien, H. E. Nursten, M. J. C. Crabbe, and J. M. Ames (Eds.), The Royal Society of Chemistry, Cambridge, England.

Pokorny, J. (1981). Browning from Lipid-Protein Interactions. Prog. Food Nutr. Sci., 5, 421-428.

Pokorny, J. (1998). Substrate Influence on the Frying Process. Grasas Aceites, 49, 265-270.

Pomeranz, Y., and Meloan, C. E. (1978). Food Analysis: Theory and Practice, Revised Edition, AVI Publishing, Westport, Connecticut.

Porta, E. A. (1991). Advances in Age Pigment Research. Arch. Gerontol. Geriatr., 12, 303-320.

Porta, E. A., and Hartroft, W. S. (1969). Lipid Pigments in Relation to Aging and Dietary Factors in Pigments in Pathology, pp. 191-235, W. Wolman (Ed.), Academic Press, New York.

Potter, N. N., and Hotchkiss, J. H. (1995). Food Science, $5^{\text {th }}$ Ed., Chapman and Hall, New York.

Sayre, L. M., Arora, P. K., Iyer, R. S., and Salomon, R. G. (1993). Pyrrole Formation from 4-Hydroxynonenal and Primary Amines. Chem. Res. Toxicol., 6, 19-22. 
Sapers, G. M. (1993). Browning of Foods: Control by Sulfites, Antioxidants, and Other Means. Food Technol., 47 (10), 75-84.

Schaich, K. M. (1980). Free Radical Initiation in Proteins and Amino Acids by lonizing and Ultraviolet Radiations and Lipid Oxidation - Part III: Free Radical Transfer from Oxidizing Lipids. CRC Crit. Rev. Food Sci. Nutr., 13, 189-244.

Smith, O. (1987). Effect of Cultural and Environmental Conditions on Potatoes for Processing in Potato Processing, 4th Ed., pp. 74-147, W. F. Talburt and O. Smith (Eds.), AVI-van Nostrand Reinhold, New York.

Sohal, R. (Ed.) (1981). Age Pigments, Elsevier, Amsterdan.

Stansby, M. E. (1957). Oxidative Deterioration in Fish and Fishery Products. I. Introduction. Com. Fisheries Rev., 19, 24-26.

Strehler, B. L. (1964). On the Histochemistry and Ultrastructure of Age Pigment in Advances in Gerontological Research, pp. 343-384, B. L. Strehler (Ed.), Academic Press, New York.

Strehler, B. L. (Ed.) (1977). Time, Cells, and Aging, 2nd Ed., Academic Press, New York.

Suyama, K., and Adachi, S. (1979). Reaction of Alkanals and Amino Acids or Primary Amines. Synthesis of 1,2,3,5- and 1,3,4,5-Substituted Quaternary Pyridinium Salts. J. Org. Chem., 44, 1417-1420.

Szweda, L. I., Uchida, K., Tsai, L., and Stadtman, E. R. (1993). Inactivation of Glucose-6-phosphate Dehydrogenase by 4-Hydroxy-2-nonenal. Selective Modification of an Active-site Lysine. J. Biol. Chem., 268, 3342-3347.

Theander, O. (1981). Novel Development in Caramelization. Prog. Food Nutr. Sci., 5, 471-476.

Tressl, R., Wondrak, G. T., Krüger, R.-P., and Rewicki, D. (1998a). New Melanoidin-like Maillard-Polymers from 2-Deoxypentoses. J. Agric. Food Chem., 46, 104-110.

Tressl, R., Wondrak, G. T., Garbe, L.-A., Krüger, R. P., and Rewicki, D. (1998b). Pentoses and Hexoses as Sources of New Melanoidin-like Maillard Polymers. J. Agric. Food Chem., 46, 1765-1776.

Tsuchida, H., Komoto, M., Kato, H., and Fujimaki, M. (1975). Isolation of Deoxyfructosazine and its 6-Isomer from the Nondialyzable Melanoidin Hydrolyzate. Agric. Biol. Chem., 39, 1143-1148.

Ulrich, P. (1998). Pharmacological Reversal of AGErelated Protein Crosslinking with Agents that Cleave $\alpha$-Dicarbonyls in The Maillard Reaction in Foods and Medicine, pp. 322-326, J. O'Brien, H. E. Nursten, M. J. C. Crabbe, and J. M. Ames (Eds.), The Royal Society of Chemistry, Cambridge, England.

Vasan, S., Zhang, X., Zhang, X. N., Kapurniotu, A., Bernhagen, J., Teichberg, S., Basgen, J., Wagle, D., Shih, D., Terlecky, I., Bucala, R., Cerami, A., Egan, J., and Ulirich, P. (1996). An Agent Cleaving Glucose-derived Protein Crosslinks in vitro and in vivo. Nature, 382, 275-278.

Venolia, A. W., and Tappel, A. L. (1958). Brown-Colored Oxypolymers of Unsaturated Fats, J. Am. Oil Chemists' Soc., 35, 135-138.

Xu, G., and Sayre, L. M. (1998). Structural Characterization of a 4-Hydroxy-2-alkenal-derived Fluorophore that
Contributes to Lipoperoxidation-dependent Protein Cross-linking in Aging and Degenerative Disease. Chem. Res. Toxicol., 11, 247-251.

Yamamoto, A., and Kogure, M. (1969). New Applications of Amino Acids in Food Industries. 1. Elimination of Rancid Odor in Rice by L-Lysine. Nippon Shokuhin Kogyo Gakkai-shi, 16, 414-419.

Yin, D. (1996). Biochemical Basis of Lipofuscin, Ceroid, and Age Pigment-like Fluorophores. Free Radical Biol. Med., 21, 871-888.

Yin, D., Yuan, X., and Brunk, U. T. (1995). Test-tube Simulated Lipofuscinogenesis. Effect of Oxidative Stress on Autophagocytotic Degradation. Mech. Ageing Dev., 81, 37-50.

Zamora, R., and Hidalgo, F. J. (1992). Browning and Fluorescence Development during Microwave Irradiation of a Lysine/(E)-4,5-Epoxy-(E)-2-heptenal Model System. J. Agric. Food Chem., 40, 2269-2273.

Zamora, R., and Hidalgo, F. J. (1994). Modification of Lysine Amino Groups by the Lipid Peroxidation Product 4,5(E)-Epoxy-2(E)-heptenal. Lipids, 29, 243-249.

Zamora, R., and Hidalgo, F. J. (1995a). Influence of Irradiation Time, $\mathrm{pH}$, and Lipid/Amino Acid Ratio on Pyrrole Production during Microwave Heating of a Lysine/(E)-4,5-Epoxy-(E)-2-heptenal Model System. J. Agric. Food Chem., 43, 1029-1033.

Zamora, R., and Hidalgo, F. J. (1995b). Linoleic Acid Oxidation in the Presence of Amino Compounds Produces Pyrroles by Carbonyl Amine Reactions. Biochim. Biophys. Acta, 1258, 319-327.

Zamora, R., Hidalgo, F. J., Alaiz, M., Millán, F., Maza, M. P., and Vioque, E. (1987). Interacción entre el Glutatión y Diferentes Oxoácidos Grasos. Grasas Aceites, 38, 318-322.

Zamora, R., Hidalgo, F. J., and Alaiz, M. (1991a). Alteraciones Bioquímicas de los Lípidos en los Alimentos Vegetales. I. Formación de los Hidroperóxidos Lipídicos. Grasas Aceites, 42, 155-162.

Zamora, R., Hidalgo, F. J., and Alaiz, M. (1991b). Alteraciones Bioquímicas de los Lípidos en los Alimentos Vegetales. II. Metabolismo de los Hidroperóxidos Lipídicos. Grasas Aceites, 42, 230-238.

Zamora, R., Ríos, J. J., and Hidalgo, F. J. (1994). Formation of Volatile Pyrrole Products from Epoxyalkenal/Protein Reactions. J. Sci. Food Agric., 66, 543-546.

Zamora, R., Navarro, J. L., and Hidalgo, F. J. (1995). Determination of Lysine Modification Product $\varepsilon-N$ Pyrrolylnorleucine in Hydrolyzed Proteins and Trout Muscle Microsomes by Micellar Electrokinetic Capillary Chromatography. Lipids, 30, 477-483.

Zamora, R., Alaiz, M., and Hidalgo, F. J. (1997). FeedBack Inhibition of Oxidative Stress by Oxidized Lipid/Amino Acid Reaction Products. Biochemistry, 36, 15765-15771.

Zamora, R., Alaiz, M., and Hidalgo, F. J. (1999a). Determination of $\varepsilon-N$-Pyrrolylnorleucine in Fresh Food Products. J. Agric. Food Chem., 47, 1942-1947.

Zamora, R., Alaiz, M., and Hidalgo, F. J. (1999b). Modification of Histidine Residues by 4,5-Epoxy-2alkenals. Chem. Res. Toxicol., 12, 654-660. 